\title{
BİLGE KAĞAN İLE FARABİ'NİN DEVLET BAŞKANI HAKKINDA GÖRÜŞLERININ KARŞILAŞTIRILMASI ${ }^{1}$
}

\section{Ahmet Kamil CIHAN ${ }^{2}$}

\section{Özet}

Bilge Kağan'a (Ö. 734) göre devlet başkanı "bilge" veya "biligsiz" olur. İdeal devlet başkanları "bilge ve alp" niteliğine sahip olup, "il tutup törü iderler": Devleti kurarlar ve devletin yasalarını/töresini oluştururlar. Onlar bilge oldukları için isabetli hükümler verir, doğru seçimlerde bulunur. Bu hüküm ve seçimler halkın bayındır olmalarını sağlar. Bilge kağanların belirlediği esastan/töreden ayrılan kağanlar "biligsiz" iş tutar, hükümleri ve seçimleri isabetsiz olur ve sonuçta halkı da devleti kaybeder. Onları yeniden toparlamanın yolu Bilge kağanlarca düzenlenmiş töreye bağlanmaktan geçer.

Farabi’ye (Ö. 950) göre devlet başkanı güttükleri gayeye göre fazıl ve cahil olur. İdeal başkan fazıl gaye güdüp, sağlıklı düzenlemeler yapan başkandır. Onun birçok özellikleri vardır. Her şeyden önce o "hikmet" sahibidir. Kendisi ve halkı için gerçek mutluluğa ulaştıracak düzenlemeler yapar. Sahip olduğu "hikmet"i, nazari ve ameli yönüyle toplumda da meydana getirir. Böyle bir toplum fazıl toplum, devlet de fazıl/ideal bir devlet olur.

İki düşüncede de iyilik ve yetkinliğin toplumda yukarıdan aşağıya aktarıldığı fikri vardır. Yine, Bilge Kagan'daki bilge başkan fikri ile Farabi'deki hikmet sahibi başkan fikri, devlet başkanının hangi niteliğe sahip olması gerektiğini çok açık ve ortak bir şekilde ortaya koymaktadır. Ayrıca, toplumsal iyiliğin, bilge başkanların koyduğu töreye/kanunlara uymaktan geçtiğii, toplumsal kötülüğün de bilgelik ve hikmete göre konulmuş kurallardan ayrılmakla ortaya çıktığı fikri vardır. Bilge Kağan daha çok dünyevi iyilik üzerinde dururken Farabi dünyevi ve uhrevi iyilik üzerinde durmaktadır. Farklı yönler mevcut olmakla birlikte her ikisinin de benzer veya ortak düşünceleri, ikisini de Türk Devlet Geleneğinde buluştuğunu göstermektedir.

Anahtar Sözcükler: Türk düşüncesi, Bilge Kagan, Farabi, Siyaset, Başkan

\section{A Comparative Study of Bilge Kagan and al-Farabı on Presedent}

\footnotetext{
Bu yazı 13-15 Kasım 2014'de Eskişehir'de icra edilen " "Medeniyet Düşünürü Farabi Uluslararası Sempozyumu"nda sunulan bildirinin, gözden geçirilmiş son şeklidir.

2 Erciyes Üniversitesi İlahiyat Fakültesi Öğretim Üyesi, akcihan@erciyes.edu.tr Orcid No: 0000-0002-41554048
} 


\section{Summary:}

According to Bilge Kağan (d. 734), the president of state becomes "wise" or "ignorant". The ideal presidents of state are "wise and brave". They establish the state and form the laws or customs of the state. Because they are wise, they make correct judgments and make right choices. These provisions and elections ensure that the people prosper. The president who leave the laws or customs of the state which determined by the wise presindents do things in ignorance, his rulings and elections are inaccurate and as a result, their people lose the state. The way to get them together again is through being connected to the custom arranged by wise presidents.

According to Farabi (d. 950), the presidents becomes virtuous or ignorant according to their purpose. The ideal president is one who pursues a virtuous goal and makes healthy arrangements. It has many properties. First of all, he is a "wisdom". He makes arrangements that will bring true happiness for himself and his people. He brings about the "wisdom" they possess in the society in terms of theoretical and practical. Such a society would be a virtuous society, and the state would be a virtuous / ideal state.

Both opinions have the idea that goodness and competence in society are transferred from top to bottom. Again, the idea of the wise president in Bilge Kagan and Farabi reveals very clearly what qualification a head of state should have. In addition, it can be seen the idea that social good comes from obeying the rules of wise presidents, and that social evil comes about by departing from the rules established according to wisdom. While Bilge Kağan focuses more on earthly goodness, Farabi emphasizes on earthly and ethereal goodness. Similar or common ideas of both show that they both meet in the Turkish State Tradition.

Keywords: Turkish Thought, Bilge Kagan, al-Fārābī, Politics, Presedent

\section{Kisaltmalar/Abbrevations:}

D: Kül Tigin Yazıtı Doğu yüzeyi/East Side of Kül Tigin Inscription

G: Kül Tigin Yazıtı Güney yüzeyi/South Side of Kül Tigin Inscription

\section{Giriş}

Bilge Kağan, Orta Asya steplerinde barışçıl bir dünya kurmak isteyen ve bunu da başarmış olan Göktürk (ya da Kutluk) devletinin bir kağanıdır. (Gumilöv, 413) Faaliyetlerini kardeşi Kül Tigin (731) adına Bugün Moğolistan'da bulunan, Orhon vadisinde ebedi taşlara 
yazdırdığı abidelere yazdırtmış ve orada düşünce dünyasına dair ipuçlarını da vermiştir. Dikkat çeken konulardan biri de kağanlarla ilgili kanaatidir. Devletin ve toplumun mukadderatını kağana bağlamış, kağanların çeşitlerini, niteliklerini ve başarılarını mensup olduğu siyaset geleneğine bağlı olarak abidelere yansıtmıştır.

Diğer taraftan, Farabi (ö. 980), Ortaçağda siyaset felsefesinin gerçek anlamda canlandırıcısı olmuş, birçok kaynaktan yararlanarak kıymetli bir miras bırakmıştır. Bu mirasın kaynaklarını öncelik sırasına göre belirtmek gerekirse geçmişten kendine kadar gelen felsefi birikim, içinde bulunduğu dini kültür, aile ve çocukluk çevresinden aldığı eğitim olarak sıralayabiliriz. Farabi'den bahseden eserler, kaynakları içinde felsefi arka plan ve İslam dinine birçok kez atıfta bulunur. (bk. Bayraklı, 1983, 121; Aydınl1, 1987; Walzer, 1990, 237-239, 245, 260-262) Fakat aile çevresinden aldığı kültür üzerine yapılan atıf ve tetkikler oldukça azdır. (Küyel, 1984/1; 1984/2; Cihan, 2003; Erdoğan, 2020, 177). Oysa ondan bahseden kaynaklar, künyesini sıralarken Türk filozofu, Farab ilinin Vesic Kalesi komutanın oğlu, Tarkan torununun oğlu ve Muzaffer komutan olarak tanıtır. (Korkut, 2012, 125-6)

Bu yazıda Türk devlet adamlarından Bilge Kağan ile Türk düşünür Farabi’nin Devlet Başkanı (aynı konudaki) görüşleri mukayese edilecek ve neticede benzer olan konulara dikkat çekilecek ve bu benzerliğin muhtemel sebeb/leri gösterilmeye çalışılacaktır.

\section{Bilge Kağan’a Göre Devlet Başkanı}

Bilge Kağan'ın asıl adı Tarduş-Şad Mogilan olup, II. Göktürk (ya da Kutluk) Devletinin kurucu devlet başkanı İlteriş Kağan'ın oğludur; amcası Kapagan Kağan'dan sonra yaklaşık 24 y1l devleti yönetmiştir. (Gumilov, 1999, 399)

Hakanlığı sırasında vefat eden kardeşi Kül Tigin'in adına anıt mezar yaptırmış ve hazırladığı bir metni abideye yazdırmıştır. (Tekin, XII) Dönemin tarihi olaylarına 1şık tutmasının yanı sıra çeşitli konulardaki düşüncelerini içermesi açısından bu metin Türk düşüncesi açısından oldukça önemlidir.

Bilge Kağan, devlet başkanı için "kağan” sözcüğünü kullanır ve kağanlık için, kağanın elinde olan ve olmayan birtakım esaslar kurgular. Kağanın elinde olmayan esasları şu üç maddede belirtilebilir: 
1-Tengri, Türk boylarının adlarının, sanlarının yok olmasını dilemez. (D, 27) Hatta gökte ve yerde ne varsa onlar da bu dileğe katılır. (D, 10-11). Bu, genel anlamda Tengrinin ve oluş içindeki nesnelerin Türk halkına dönük kayrası/desteği olarak görülebilir.

2- Yine, kağan olacak kişinin, Tengri tarafından yarlıganması/istenmesi gerekir ki, bu da birinci maddede sıralanan yarlıgamanın taayyünü/belirlenimidir. Bu isteğin bir başka esasla buluşması gerekir.

3- Kağan olacak kişinin, hanedana mensup olması, yani "kut"lu olmasıdır. Şöyle ki, Bilge Kağan'a göre gökyüzü ile yeryüzü kılındıktan sonra ikisinin arasında kişioğlu kılınmış, onların da üzerlerine Bumin ile İştemi, kağan olarak tahta oturmuştur. (D, 1) Buna göre kişioğlu üzerine hakan olacak kişinin kut'lu bir aileden gelmesi gerekir. (G, 9; D, 29)

Kağanın elinde olan esaslar da şöyledir: Kağanlar "bilge" veya "biligsiz" olur. Şöyle ki, kimi devlet başkanları "bilge ve alp" niteliğine sahiptir. Bilgelik, bilgisinde ve seçiminde isabetli olan kağanın sıfatıdır. Zira onların bilgilenme sürecinde Tengri'nin desteği vardır. (Cihan, 2002/2). Tengri onları tepesinden tutup yükseltir. (D, 11) Kağan bir eylemi belirlerken veya karar verirken mevcut durumu ve halkın karakterini çok iyi tanır. (G, 8) Yani, kullanacağı takdir hakkını, şartlar ayan-beyan olduktan sonra kullanır. Bu da ona isabetli seçimler yapmasına yol açar. Yönetim için oluşturdukları kadroyu da kendi gibi bilge ve alp kimselerden seçer. Böyle bir kağanın buyruk beyleri de halkı da düzgün olur, uyum içinde bulunurlar. (D, 3)

Bilge Kağanların en önemli başarısı il tutmak, törü itmek ve törüye göre halkı eğitmektir. (D, 1) İl, yani devlet, farklı boyları barış içinde tutmakla, onlara haklarını dağıtmak ve korumakla, dağıtılan hakkı gasbeden düşmanla savaşmakla olur. Kağan, kazanılan topraklarda Türk boylarını düzenli bir şekilde yerleştirir. Böylelikle boyları barış içinde tuttuğu gibi gerektiğinde kimlerden ne ölçüde destek alacağını da önceden hazırlamış olur. Tutulan ilin/kurulan devletin devamı için onları bir arada tutacak esasa gerek vardır ki, o da törüdür. Törü, Türk boylarının nazari ve ameli konulardaki kurallarını içerir. Bir teşbihle, il ile törü beden ile ruh gibidir. Nasıl ruh bedene hayat veren, onu varlıkta tutan ve çekip çeviren manevi cevher olarak anlaş1lıyor ise törü de ili ayakta tutan, onu çekip çeviren (tedbir eden, yöneten) bir esastır. Gök çökmedikçe yer delinmedikçe il ve törü ayakta kalır. Eğer il, elden gidiyorsa bu, yönetim ve halkın törüden ayrılmasından ileri gelir. (D, 23) Törüden uzaklaşan, ilsiz ve hakansız kalmış halkı toplamanın ve birleştirmenin yolu, onları, ataların törüsüne göre toplamaktan ve eğitmekten geçer. (D, 13) Bilge kağanlar, gece gündüz çalışır, fakir boyları 
toplar, aç boyları tok yapar, onları zengin kılar, azı çoğaltır (G, 10, D, 16) Halkı, su ile ateş gibi birbirine zıt kutuplara ayırmaz; dağılan boyları toplar, öleceği diriltir; boylarını/siyasi birliği en güçlü boy yapar, (D, 27-28) toprakları düzene koyar, toplumsal refah o derece yükselir ki, köleler bile kölelere sahip olur. (D, 21) Bilge kağanlar iyi bilir ki, Ötüken yış/merkez olmalıdır. Devletin merkezi, düşman saldırılarına karşı emniyet içinde olması gerektiği gibi, öz/milli kültürün de korunduğu bir yer olmalıdır. (G, 3, 8) Bilge kağanlar, içerde halkın karakterini iyi bildiği gibi, dışarıda da düşmanların da karakterini çok iyi tanır. Onların tatlı dili ve hediyelerine kanmaz, onların gerçek düşüncelerine göre önlemler alır. Ülke içindeki bilge ve iyi insanları korur, aydın insanlara sahip çıkar. Zira düşmanlar onları yürütmek/yaşatmak istemez. (G, 5-6)

Ne var ki, Bilge Kagan’a göre, devletin başına gelen kağanlar her zaman "bilge” olmaz. Zira oğullar, babalar gibi kılınmamıştır. (D, 5) Kimi kağanlar babaları gibi bilge değil "biligsiz" ve yablak/kötü kağan olur. Kendine benzer karakterdeki insanlarla yönetim kadrosunu oluşturur. Buyruk beyleri de biligsiz ve yablak olur. Beyler ve boylar birbirine karşı düz olmayı ve uyumu bırakır. Böyle yönetimin hüküm sürdüğü bir yeri, düşmanlar da rahat bırakmaz. Orada fitne ve fesat çıkartır. İşte, devletin başındaki kağan ve yönetim kadrosu bilgisiz olur, beyleri ve boyları törüyü bırakır ve hiç eksik olmayan dış tahrikler etkin olursa tutulan il/kurulan devlet elden çıkar. (D, 5-7) İlli boylar ilsiz, kağanlı boylar kağansız kalır. (D, 6-7)

Biligsiz kağanlar, öz kültürü terk edip yabancı kültüre özenir, yönetimdeki hataları sebebiyle kendi boylarının çocuklarını başkalarına köle yapar, toplumunu düşmanlarına hizmet ettirir, boyları toparlayamadığı için düşmanlara olan bağımlılık sürer gider. İşte ilsiz ve kağansız kalmış boyları, hizmetçi olmuş boyları, töreyi bırakmış boyları, bilge kağanların koyduğu töreye göre yeniden yaratan, bu töreye göre eğiten kağanlar çıkar ve çıkmıştır da. İstemi ile İlteriş böyle bir kağandır. İstemi ile İlteriş, Tengri yarlıkadığı için, illi halkları ilsiz, hakanlı halkları hakansız bırakmış, düşmanlarını kendilerine bağımlı hale getirmiş, dizlilere diz çöktürmüş, başlılara baş eğdirmiştir. (D, 15) İşte halk, böyle bir hakanın ağzına bakar, o ne söylerse onu tutar. $(\mathrm{G}, 2)$.

Buraya kadar yapılan tasvirler, bir hakanın gözüyle devlet tecrübesini yansıtan özlü ifadelerdir. Arkasında bireysel deneyim söz konusu olduğu gibi, Türk devlet geleneğinin izleri de vardır. Teorik bilgilerden çok, çocukluktan itibaren alınan bir terbiye, idarecilikten itibaren görülen bir hayat tecrübesi bu fikirlerde kendini göstermektedir. 


\section{Farabi’ye Göre Devlet Başkanı}

Farabi için devlet başkanına olan ihtiyaç, onun mutluluk teorisi ile yakından ilgilidir. Ona göre mutluluk hayatın en temel amacını oluşturur. Herkes mutluluğu, bir yetkinlik/kemal olduğu için arzu eder ve onu elde etmenin yollarına bakar. Ne var ki, mutluluğun ne olduğunun tespiti hususunda aynı düşünmez. İnsanlar servet, iktidar, lezzet, ilim gibi farklı hedefleri mutluluk olarak belirler. (Farabi, 1992/2, 227-8) Bundan da anlaş1lır ki gerçek mutluluğun ne olduğunu belirlemek hayati önem taşır. Aksi halde yanlış hedefler uğruna hayat heder edilir. İşte tam da bu noktada insanlara gerçek mutluluğun ne olduğunu ortaya koyacak kılavuza gerek vardır. Bu kılavuz, makul ve tasavvur edilen bir şey olarak gerçek mutluluğu ve onu elde etme yollarını tespite çalışan bir "hakiki filozof" yahut insanları ikna yollarıyla tahayyül edilen bir şey olarak gerçek mutluluğa çağıran bir "peygamber"dir. (Farabi, 1992/1, 181, 185)

Topluluk bireylerden oluştuğu için, onları idare eden bir reis mutlaka vardır. Yönetimin şekli de reisin gayesi dikkate alınarak faziletli, cahil (zaruri, beddale, hasislik, tagallup ve cemaiyye, fasık, dalle veya mübeddel) şeklinde sıralanır. (Farabi, 1985, 131-133) Farabi onur kazanma, üstün gelme, itaat edilme, servet ve lezzetlerden yararlanma gibi cahilce gayeler güden olan bir yöneticinin, kadim filozoflarca melik/kral sayılmadığını açıkça bildirir. (Farabi, 1986, 48-9) Bu itibarla reisleri "Faziletli ve faziletli olmayan" reisler diye ikiye ayırmak mümkündür. (Krş, Farabi, 1991, 55) Faziletli olmayan reisler, faziletli reislere zıttır, faziletli olmayan yönetimler de faziletli yönetime zıttır. (Farabi, 1985, 124) Öyleyse gerçekte melik/kral ya da faziletli reis kabul edilen yönetici kimdir, hangi niteliklere sahiptir ve ne gibi başarıları vardır, onu tespit etmek gerekir.

Gerçek melik/kral, gerçek mutluluğu bilen ve bunu şehir halkına vermek isteyen kişidir. Böyle biri sadece kendini düşünmediği, başkalarını da düşündüğü için mutlulukça tamdır. (Farabi, 1986, 47) Maksadı, şehirlerde kullanıldığında insanları bu dünyada birçok iyiliğe ahirette de en yüksek mutluluğa ulaştıracak huyları ve melekeleri devlete ve topluma yerleştirmek ve korumak olan yönetim, faziletli yönetimdir; yöneticisi de faziletli reistir. (Farabi, 1991, 54-5)

Daha önce mevcut olmadığı halde faziletli hayatı ve melekeleri devlete ve topluma yerleştiren ve onları cahil yönetimden faziletli yönetime dönüştüren yönetime "ilk reislik", yöneticisine de ilk reis denir. (Farabi, 1991, 52) Farabi nazarında faziletli siyaset ile cahili siyaset arasında hiçbir şekilde ortaklık yoktur. (Farabi, 1986, 92) Farabi için imam/önder, melik, filozof ve 
yasa koyucu aynıdır. (Demirpolat-Ülger, 2020, 174) Şöyle ki, ona “filozof” denmesi nazari fazileti itibariyle; "yasa koyucu” denmesi, ameli veya iradi makullere ait şartları çok iyi bilmesi itibariyle, "melik” denmesi gücü ve iktidarı itibariyle, “önder” denmesi de maksadı ve kemalinden dolayı tâbi olunması itibariyledir. (Farabi, 1992/1, 187-9)

Farabi için gerçek melik/ilk reis, hikmet/felsefe, tam taakkül/pratik düşünme, ikna gücü, hayal etme gücü, bedeniyle cihat etme kudreti ve bedensel bir engelinin olmaması gibi niteliklere sahip olmalıdır. (Farabi, 1986, 66) Amacı yalnızca iyi olanı kazanmak olan sanat, hikmettir. İyi olan şey de sadece "ilim" ile "ilme uygun amel"den ibarettir. Bu da nazari ve ameli felsefedir. (Farabi, 1992/2, 256) Hikmetin elde edilmesi faal ak1lla temas neticesi olur; bazen nazari ve ameli ak1l yönünden kemale eren ve mütehayyile gücü tam olan birine Allah vahyeder ve edilgin akılda hâsıl olan şeyle o kimse "hikmet sahibi", "filozof" ve "taakkül sahibi" olur; mütehayyile gücünde hâsıl olan șeyle uyarıcı ve haberci bir "nebi" olur. Böyle bir insan mutluluğa ulaştıracak her fiile vakıf olur. Farabi'ye göre taakkülün birçok çeşidi olsa da özü şudur: İnsan için gerçekte büyük hayır olan şeyi elde etmek üzere yapacağı şeyde en uygun (aslah) ve en iyi (ecved) olanı düşünmedir. Taakkül insani iyiliklerin idrakine ilişkin olduğu için, o hikmet değildir. Zira hikmet gayeyi bildirirken; taakkül gayeye ulaştıran vasıtaları bildirir. İkisi ile insanın mutluluğu tamamlanır. (Farabi, 1986, 55-62) Faziletli yönetim işi tam olarak nazari felsefe ve taakkül gücünü bu sanata bitiştirip, bu sanatın küllilerini bilmekle olur. (Farabi, 1991, 60) İlk reis, bildiği hususları hem sözlü olarak tahayyüle dönüştürme gücüne hem de insanları mutluluğa ve ona götürecek fiillere yöneltme gücüne sahiptir. Aynı zamanda o cüzi fiilleri yerine getirmede bedenen sağlam ve azimkar olur. (Farabi, 1985, 125-126)

Farabi faziletli başkanda bulunması gereken diğer özelliklerden de söz eder: Bunlar, 1.organların tam olup, dilediği vakit onları kullanabilme, 2. kendisine söyleneni, söyleyenin maksadına uygun olarak anlama, 3. idrak ettiklerini unutmama, 4. çok zeki olma, bir şeyin neye delalet ettiğini kavrama, 5. zihnindekini kolayca ifade etme, 6. öğrenmeyi sevme ve zorluklarına katlanma, 7. hissi lezzetler peşinde koşmayı sevmeme, 8. doğruyu ve doğru söyleyenleri sevme, 9. Yüksek ruhlu olma ve nefsini bayağı şeylerden üstün tutma, 10. servet peşinde koşmama, 11. adaleti sevme ve insaflı olma, mazlumları destekleme, 12. Yapılması gereken konularda azimli ve kararlı olmaktan ibarettir. (Farabi, 1985, 127-129)

Farabi, nebilik şartı bulunmadığı durumda diğer şartları taşıyan birinin reis olacağını söyler. (Farabi, 1985, 129) Şayet hikmete sadece birisi, geriye kalan özelliklere ve şartlara başka 
birisi sahip olursa ikisi erdemli şehrin reisi olur, fakat hikmeti barındıran söz sahibi olur. Şayet bu özellikler birkaç kişide dağılmış olarak bulunuyorsa onlar reis olur ve yine hikmeti barındıran "söz sahibi”" olur. Bu kişiler, gerçek bir melikin yerine geçmiş olur. (Farabi, 1985 129; 1986, 66) Şayet hikmet olmadan diğer özellikler ve şartlar mevcut olursa erdemli şehrin meliki yok demektir. Hikmetin nispet edileceği biri olmazsa şehir kısa sürede helak olur. (Farabi, 1985, 130) Farabi ilk reisin özelliklerini taşımayan reise, gelenekçi reis adını verir. Şu halde faziletli yönetim, 1- ilk yönetim ve 2- ona tâbi yönetim olmak üzere iki çeşittir. İlk yönetim, şekli ne olursa olsun, daha önce mevcut olmadığı halde devlete ve topluma faziletli hayatı ve melekeleri yerleştirir. İlk yönetime tabi olan gelenek yönetimi ise onun izinden gider. (Farabi, 1991, 52)

Anlaşılacağı üzere, faziletli reis, tabiat itibariyle güçlü özelliklere sahip olduğu gibi, iradesi yönünden de birtakım kazanımlara sahiptir. Reis, bu kazanımlarını talim ve tedip yoluyla toplumda meydana getirir. Talim, nazari faziletleri sözlü yollarla, tedip ise ahlaki fazileti ve ameli sanatları toplumda meydana getirmedir. Tedip topluma ikna yoluyla verildiğinde kabul edilmiyorsa kanun gücüyle zorla verilir. (Farabi, 1992/1, 164-168) Bu itibarla devlet başkanı toplumun öğretmeni ve eğitmeni/mürebbisidir. (Farabi, 1992/1, 169-170)

Mademki melik, toplumun öğretmeni ve mürebbiyesidir, öyle ise muhataplarının zihni kapasitesini iyi bilmesi gerekir. Bu düşünceden hareketle Farabi toplumu, avam (cumhur) ve seçkinler (Havas) diye iki kısma ayırır. Cumhuru bilgilendirmede çeşitli ikna yolları ve tahayyül kullanılırken seçkinlerin bilgilendirmede burhan/kanıtlama yolları ve makullerin bilgisi kullanılır. (Farabi, 1992/1, 180-181) Farabi birinci yolla öğretilen şeye mille/din/gelenek, ikinci yolla öğretilen şeye de felsefe adını verir. Ona göre felsefenin burhanla ve makul olarak verdiğini, mille ikna yollarıyla hayal edilmiş olarak verir. (Farabi, 1992/1, 185) Farabi’ye göre melik, burhanla hasıl olan makulleri ümmet içinde misalleriyle ve ikna yoluyla tasdik ettirir; faziletli fiilleri bir bir sayar ve ümmeti etkileyecek sözler kullanır. (Farabi, 1992/1, 171-2)

Avamın toplumu oluşturmasından hareketle Farabi, devlet başkanının en önemli görevinin milleyi belirlemek olduğunu düşünür. Ona göre mille, ilk reis tarafından aşiret, şehir vb cinsten belli bir grup için onlarla sınırlı bir hedef uğruna belirlenen görüşler ve şartlarla kayıtlı, takdir edilmiş fiillerdir. İlk reis faziletli ise hakiki mutluluğu gaye edinir ve belirlediği mille de faziletli mille olur. Bundan dolayı mille, ilk reisin gayesine göre nitelenir. Reis servet, lezzet ve övülme gibi cahil hedefler koyabileceği gibi yoldan çıkmışların gayesini 
hedef olarak koyabilir. Hatta bazen kasten cahilce bir hedef koyabilir. (Farabi, 1991, 43-44) Asıl olan, faziletli mille olduğu için, Farabi onun üzerinden millenin içeriğini şöyle açıklar: Milledeki görüşler ya Allah, ruhaniler, alemin yaratılışı, insanda nefsin ve aklın ortaya çıkışı, ölüm ve ötesi ile ilgili nazari konulardır ya da geçmişteki ve günümüzdeki iyi ve kötü melikleri öyle vasfeden şeylerle ilgili iradi konulardır. Milledeki fiiller ise Allah'ı, ruhanileri, iyi insanları yücelten sözler ve fiiller, kötü yöneticileri aşağılayan sözler ve fiiller, şehir halkının yapması gereken fiiller ve bu fiillerdeki adaletin bildirilmesidir. (Farabi, 1991, 4546) Farabi'ye göre, mille reise ya tamamıyla belirlenmiş olarak vahyedilir ya da vahiyden ve vahyeden alınan güçle reis onu kendisi belirler; bu durumda fiilleri takdir etmesi için şartların ona açık/münkeşif olması gerekir veyahut mille iki yolla birlikte belirlenir. (Farabi, 1991, 44)

İlk başkan savaş, olayın vuku bulmaması ya da konunun sorulmaması gibi bir sebeple fiillerin hepsini takdir etmeyebilir. Onlar sonradan gelen reisler tarafından belirlenir. Sonra gelen ilk reisin şartlarını taşıyorsa ilkinin takdir etmediği fiilleri ikinci takdir eder. Yapılan yeni takdir, önceki hatalı olduğu için değil şartlar değiştiği içindir. Sonraki gelen ilk başkanın şartlarını taşımıyorsa ilk başkanın yaptıkları ve maksadı dikkate alınarak, yani geleneğe göre belirlenir. (Farabi, 1991, 49-52)

İlk reisin önemli bir işlevi de adaleti temin etmektir. Adalet faziletli şehir halkının tamamına ait iyiliklerin, yani can güvenliği, mal, bağışlar, kamusal statünün dağıtımında ve korunmasında ortaya çıkar. Ona göre şehir halkının hak ettiği bir pay muhakkak vardır. Bu payın altı veya üstü, zulümdür. Devlet başkanı dağıtılan iyilikleri şehir halkında korumalıdır. (Farabi, 1986, 71-73) Melik şehri idare ederken hekim gibi davranır. Zira hekim bir organın tedavisi yaparken bütün bedeni dikkate alır. Aynı şekilde, melik de şehre iyiliği dağıtırken şehrin bütününe zarar vermemesi gerekir. Şehrin her bir cüzü, mertebesi kadar iyilikten faydalanmalıdır. Şehrin bir cüzüne diğerlerine de bulaşma ihtimali olan bir fesat ulaşırsa geriye kalanların salahı için o cüzü uzaklaştırır. (Farabi, 1986, 41-43)

İlk reisin devletteki konumu Allah'ın aleme ve mevcudata olan konumuna benzer. Alemin yöneticisi Allah olduğu gibi ilk reise milleyi ulaştırması sebebiyle, faziletli şehrin yöneticisi de gerçekte Allah olur. Alemi yönetmekle toplumu yönetmek arasında bir uyum olsa da cihetleri, yani biri tabii diğeri iradi olmaları itibariyle birbirinden farklıdır. Yönetimle farklı birçok iş tek bir amaç uğruna tek bir işe dönüşmüş olur. (Farabi, 1991, 63-66) Anlaşıldığ1 kadarıyla bununla, tabii iyiliğin iradi alanda da sürdürülmesi gerektiğine işaret edilmektedir. 


\section{Karşılaştırma}

Devlet başkanlarının niteliği ve işlevi üzerine burada verilen malumat bazı ölçekler dikkate alınarak karşılaştırıldığında Bilge Kağan ile Farabi arasında ortak ve farklı olan taraflar açığa çıkacaktır.

1.Devlet Başkanıyla ilgili temel kategoriler: Bilge Kagan devlet başkanlarını "bilge ve biligsiz" olarak iki temel kategoriye ayırır. "Bilge" sıfatını ili tutan, töre yapan veya töreye göre halkı toplayıp eğiten başarılı başkanların sıfatı olarak kullanır. "Biligsiz" sıfatı ise ili yönetmede ve töreyi korumada itinasız davranan, nihayetinde ili kaybeden başkanın sıfatı olarak kullanır. Farabi ise başkanları en temelde "Faziletli ve cahil" olarak ikiye ayırır. "Faziletli" terimi halkını gerçek mutluluğa sevk edecek düzenlemeleri yapan ve bu uğurda onları eğiten başkanın sıfatı olarak kullanır. "Cahil” terimi ise gerçek mutluluğun mahiyetiyle ilgili yanlış, birbirinden farklı birçok hedef tespit edip, halkını bu uğurda kullanan başkanın sıfatı olarak kullanılır. Temel kategorilerde ikisi arasındaki benzerlik hemen dikkati çekecektir. Muhteva bakımından Bilge Kağan dünyavi ve Türk toplumuyla ilgili hedeflerle sınırlı iken Farabi, faziletli reis düşüncesiyle dünya ve ahiret mutluluğu ile ilgili olup, herhangi bir toplumla sınırlı değildir.

2. Başkanın Nitelikleri: Bilge Kagan için ideal devlet başkanı bilge ve alp olur. Bilgeliği sayesinde içeride halkına, dışarıda düşmana karşı yapması gereken işleri bilir ve yapar. Farabi için de ideal başkan faziletli olur. Gerçek mutluluğu bilir ve halkının da ona ulaşması için tedbirler alır. Bilge kagan, Tengrinin dilemesine, tepesinden tutup yükseltilmesine mazhar olur. Bu itibarla ideal başkan Tengri ile bir şekilde ilişki içinde olur. Tengri onu kağan olarak takdir eder. Farabi için de faziletli reis Faal akıl ile ilişki içindedir. Ondan hikmet ve/ya nübüvvet alır. Dolayısıyla Bilge Kagan ve Farabi, ideal başkanı metafizik bir ilke ile ilişkilendirir. Bu da aralarındaki ortak hususlardan biridir.

3. Bilgelik: Bilge Kağan il tutan, törü iden ve halkı törüye göre eğiten başkanları "bilge" olarak niteler. $\mathrm{Bu}$ nitelik, geçmişteki kağanlar için olduğu gibi kendisi için de geçerlidir. Farabi de faziletli reisin ilk şartını "hikmet" olarak ortaya koyar. Hatta reislik için gereken şartlar dağılmış olsa da hikmeti taşıyan şahsın diğerleri içinde reis olacağını, böyle biri bulunmadığı takdirde o halkın gerçekte reissiz kalacağını ifade eder. Bu da ikisinin da bilge veya hakîm vasfını olmazsa olmaz şart olarak belirlediğini ortaya koyar. Diğer taraftan, bilge ile hakîm vasfi, içerik açısından birebir örtüştür mü? Farabi'nin hikmet hakkındaki açıklamaları nazari ve ameli felsefe üzerinde odaklanmakta ve gerçek mutluluğun belirlenmesiyle ilgilidir. Ona götürecek yolları ve eylemleri de taakkül gücü belirler. Bilge Kağan'ın bilge kağanlarla ilgili açıklamaları daha çok Türk halkının mutluluğu ve ona 
götüren yollarla ilgilidir. Bu, Farabi'deki hikmete kısmen (ameli felsefeye) karşılık gelse de daha çok taakkül kuvvetine karşılık gelmektedir.

4. Toplumsal iyiliğin kaynă̆ı: Bilge Kağan için devletin ve halkın iyilik ve refahı devlet başkanına bağlıdır. Kagan bilge olursa yönetim de bilge olur, halk da töreli (tüz) olur. Kagan, biligsiz olursa devlet de halk ta bundan zarar görür. İl de gider töre de. Bu sebeple kaganın niteliği hayati öneme sahiptir. Zaten atasözündeki "Balık baştan kokar" ifadesi de bunu dile getirir. Farabi için de reis hayati öneme sahiptir. Zira yönetimin ve millenin hedefini o belirler. Reis iyi olursa yönetim iyi olur, belirlediği mille de faziletli olur. Aksi halde yönetim cahil, mille de cahil mille olur. Bu itibarla Bilge Kağan ile Farabi’nin “İyilik yukarıdan gelir. Baş iyi olursa aşağısı da iyi olur” anlayışına sahip olduğu görülmektedir.

5. Töre: Bilge Kağan, ideal başkanların en önemli başarısı olarak töre yapmayı, onu korumayı ve ona göre halkı eğitmeyi gösterir. Töre, bilge kağanlar tarafından, Türk halkını, belli bir gaye etrafında tutarak hayatlarını nasıl idame etmeleri gerektiğini ortaya koyan düzenlemelerdir. O Türk halkına ruh/şekil verir ve onu o kılar. Onu bırakmak öz kimlikten çıkmaktır. Başkalaşmaktır. İlsiz ve hakansız kalmaktır. İşini ve gücünü, belirsiz kağanlara vermektir. Kısaca gayesiz bir hayattır. Farabi faziletli reisin, halkın öğretmeni ve mürebbisi olduğunu düşünür. $\mathrm{Bu}$ itibarla reis, halkını dünyada salaha ve ahirette gerçek mutluluğa ulaştıracak görüşleri ve işleri belirler. Bunlar, kavramsal düzeyde düşünenler için burhanlarla, düşünemeyen çoğunluk için misallerle ve ikna yollarıyla halka kazandırılmaya çalışılır. İlki hikmete, ikincisi de milleye, yani töreye karşılık gelir. Mille, halkı tek bir ruha dönüştürür, aralarında sevgi bağı meydana gelir ve işleri adaletle yürütür. Töre ve mille kavramları arasında, kapsam istisna edilirse büyük bir benzerlik vardır. Kapsam Bilge Kağan'a göre Türk boyları iken Farabi’ye göre ilk reisin etrafındaki halk için geçerlidir.

6. Adalet: Bilge Kağan ideal başkanın, devletin sahip olduğu zenginlik, toprak vb imkanları halkına dağıttığına dikkat çeker. Esasen il olmak, farklı boyları bir arada tutmakla olur. Şayet boylar kendilerine haksızlık yapıldığına kani olursa ilden çekilir. Bu sebeple kaganların, boyları il içinde (ilin bir anlamı da barıştır) tutması gerekir. Bunu yaparken de haksızlık etmemesi, töreye göre devletin imkanlarını dağıtması gerekir. Farabi de kamuya ait olan hayratın, servet ve mertebe dağıtımını, yine halkın mertebesine göre uygulanması ve bu haliyle muhafaza edilmesini adalet olarak belirler. İdeal reisin işlevlerinden ilki ve önceliklisi adaleti ayakta tutmaktır. Bu itibarla Bilge Kağan ile Farabi, adaletin toplum içindeki işlevine müştereken dikkat çekmiştir. 


\section{Sonuç}

$\mathrm{Bu}$ karşılaştırmanın bizi getirdiği kanaate gelince, ikisi arasında birçok konuda ortak görüş vardır. Kanaatimiz o ki, Göktürk/Kutluk devletini uzun bir süre yöneten Bilge Kağan, atalarının töresinden gelen anlayış içinde olmuş ve bu töreye göre devleti idare etmiştir. İdeal kağanların nitelik ve başarılarıyla ilgili tarihi ve şahsi birikimini anıtlarda ifade etmiştir. Her ne kadar kuramsal ve kavramsal olarak siyasetle uğraşmasa da Küyel'in ifadesiyle operasyonel anlamda yaptıklarıyla bu konulara dikkat çekmiştir. (Küyel, 1994) Farabi ise devlet yönetmiş bir reis değildir. Fakat yönetimin toplum için hayati derecede önemli olduğunu düşünmüş ve bu uğurda felsefi, dini ve tarihi kültürü dikkate almış ve yararlanmış görünmektedir. Farabi'nin yararlandığı kaynaklar içinde özellikle milli kültüre dikkate çekmek istiyoruz, zira babasının komutan olması, dedelerinden birinin Tarkan olması, onun askeri ve idari tecrübesi olan bir aile ocağından geldiğini gösterir. Karakter şekillenmesinde çocukluk ve gençlik döneminin kalıcı bir etkisi olduğu da muhakkaktır. Yine, yaşadığı olaylar da bu konuda ona yardımcı olmuştur. Onun devlet başkanları hakkındaki düşüncesinin, Bilge Kağan'ın tasvir ettiği bilge kağanla büyük ölçüde örtüşmektedir. Aralarındaki benzerliği “tesadüf”e bağlamak yerine "tevarüs”e bağlamanın daha isabetli olacağını düşünüyoruz. Bu itibarla ikisinin de aynı kaynaktan içtiğini, yani Türk Devlet Anlayışından yararlanmış olduğunu söylemek mümkün görünmektedir.

\section{KAYNAKÇA}

Aydınlı, Yaşar. (1987), Farabi'nin Siyaset Felsefesinde İlk Başkan (er-Reis el-Evvel) Kavramı”, Uludağ Üniversitesi İlahiyat Fakü ltesi Dergisi, 2; 291-302.

Bayraklı, Bayraktar. (1983), Farabi'de Devlet Felsefesi, Doğuş yayıncılık, İstanbul.

Cihan, A. Kamil. (2004/1) “Farabi'nin Siyaset Felsefesinde Türk Devlet Anlayışının İzleri”, Bilimname, IV, 17-31.

----- (2002/) “Orhon Yazıtlarındaki Bilge Terimi Üzerine”, Felsefe Dünyası, 35; 89-101.

Demirpolat-Enver- Ülger Mustafa, (2020) “Farabi'de Reis, Filozof, Hakan ve kanun Koyucu kavramları", Muallim-i Sani Uzlukoğlu Farabi, İstanbul: Kitap yayınevi.

Erdoğan, İsmail, “(2020) “Farabi’nin Faal akıl Anlayışının Eski Türk düşüncesi ile Bağlantısı Üzerine”, Muallim-i Sani Uzlukoğlu Farabi, İstanbul: Kitap yayınevi.

Farabi, (1985). Kitabu Arai Ehli'l-Medineti'l-Fadıla, Neşir: A.N. Nadir, 5. Baskı, Beyrut: Darul-Meşrik

-----(1991). Kitabu'l-Mille, Neşir: Muhsin Mehdi, Darul-Meşrik, Beyrut, ikinci baskı. 
---- (1992/2). Tahsilu's-Seade, el-A'malu'l-Felsefiyye içinde, Neşir: Dr. Cafer Alu Yasin, Beyrut: Darul-Menahil.

---- (1992/2) Kitabu't-Tenbih Ala Sebili's-Seade, el-A'malu'l-Felsefiyye, Neşir: Dr. Cafer Alu Yasin, Beyrut: Darul-Menahil.

----- Fusulun Müntezaa (1986). Neşir: Dr. Fevzi M. Neccar, 2. Bask1, Beyrut: Darul-Meşrik, Gumilöv, L.N. (1999). Eski Türkler, Çev. D. Ahsen Batur, İstanbul, Birleşik yayıncılık.

Korkut, Ş. (2012) “Meşşai Geleneğin Kurucu Filozofu: Farabi”, İslam Felsefesi Tarihi, I, Editör: B. Ali Çetinkaya, Ankara: Grafiker Yayınevi.

Küyel, M. T. (1984/1) 'Kut, Farabi ve İbn Sina'daki al-Akl al-Fa'al için bir Temel Oluşturabilir mi?”, İbn Sina Doğumunun Bininci Yılı Armağanı, Derleyen: Aydın Sayılı, Ankara: TTK.

---- (1984/2)“İbn Sina'nın al-Akl al-Fa'al'ine Bir Adım Olarak Farabi'de Siyaset” İbn Sina Doğumunun Bininci Yılı Armağanı, Derleyen: Aydın Sayılı, Ankara: TTK Basımevi,

---- (1994). “Bilge Kağan bir Filozof Arhont mudur”, XI. Türk tarih kongresi Cilt II, Ankara: TTK.

Tekin, T. (1988). Orhon Yazitlar, Ankara: TTK.

Walzer, Richard. (1997) “Açıklama ve Yorumlar”, İdeal Devlet (el-Medinetu'l-Fadıla), Çev. Ahmet Arslan, Ankara, Vadi yayınları,. 